\title{
Folktales and Other References in Toriyama's Dragon Ball
}

\author{
Xavier Mínguez-López \\ Valencia University, Spain \\ ELCIS Group
}

xavier.minguez@uv.es

Departament Didàctica de la Llengua i la Literatura

Avgda. Tarongers 4

46022 València

Tel. ++34 605288430

Published in Animation: an Interdisciplinary Journal, 9(1). 2014

\begin{abstract}
:
The aim of this article is to show the relationship between Japanese folktales and Japanese anime as a genre, especially how the intertextuality with traditional tales and myth subvert its conventional use. To meet this goal I have used Toriyama’s successful Dragon Ball series, which has enjoyed continued popularity right from its first publication in the 1980s. I analyse the parallelism between Dragon Ball and a classic Chinese novel, Journey to the West, its main source. However, there are many other folkloric references present in Dragon Ball connected to religion and folktales. The author illustrates this relationship with examples taken from the anime that correspond to the traditional Japanese Folklore but that are used with a subversive goal which makes it a rich source for analysis and for Literary Education.
\end{abstract}

Keywords: animated TV series, anime, Dragon Ball, Japanese animation, Japanese folktales, Japanese religion, literary education, myth, narrative, subversion, Toriyama

Corresponding Author: Xavier Mínguez López, Departament Didàctica de la Llengua i la Literatura, 
Universitat de València Avgda. Tarongers 4, 46022 València, Spain. Email: xavier.minguez@uv.es

Pop culture is too pervasive, rampant, eclectic and polyglot to be unravelled and remade into an academic macramé pot holder[...] It's a cultural gulf defined by differences in view of how cultures are transforming and mutating through transnational activity. Pop - more than anything else - is the implosive point around which these gulfs form and the nexus of their attraction.

Philip Brophy, (2005)

The successful anime series Dragon Ball offers much insight into the complicated and interwoven relationships that exist between past and present storytelling traditions. This article specifically explores intersections between Japanese folktales and Japanese anime; I take my lead from Philip Brophy, cited above, who explains that despite its extreme complexity, popular culture helps us to understand how cultures are transformed and mutate through transnational activity. Japanese anime shows the connexions that exist between Japanese culture and a global understanding that allows its comprehension all around the world. Moist \& Bartholow (2007:29) state:

As one of the key international forms of postmodern popular culture, anime calls for a critical approach that can be as varied and complex as its object. In this case, we suggest that the way in which particular anime-tors [sic] make use of the cultural and formal resources available to them is a valuable approach. $[\ldots]$

The TV show Dragon Ball, created by Akira Toriyama, has been very popular in Europe in spite of its Japanese roots. This story started with Toriyama's free adaptation of the Chinese book, Journey to the West (Cheng'en Wu 1525/1993) but it continued to develop a very complex story, which included different intertwined sagas. Furthermore it is strongly influenced by the two main religions in Japan (Shinto and Buddhism) and also from Samurai stories and martial arts films and comics. It is a good example of how popular culture transforms and, at the same time, strengthens cultural production by adapting rich historical traditions into its form. The fact that Dragon Ball is of Japanese origin makes its analysis more difficult from a Western point of view but it also increases its appeal. As Shinobu Price (2001) points out:

[...] anime, as it is commonly called, is a delightfully inventive reference manual into the world of Japanese symbols, folklore, religion, history, social musings and aesthetic traditions. When audience members are not exclusively Japanese, anime unexpectedly becomes a vehicle for cross-cultural 
communication. (p. 153)

Toriyama's Dragon Ball is a very good example of how intertextuality allows Japanese animators to build a world starting from Japanese cultural sources but appealing to many other cultural references, Japanese and non Japanese. In this article, I shall try to show some of the different uses of folklore and other references that search different purposes, from superficial puns to subliminal subversion.

\section{Japanese Stories, Legends and Myths}

One of the interesting but also puzzling points for Western audiences is the lack of references that would enable us to interpret some scenes or even entire works. The most obvious reason lies in a cultural system that is radically different from the Western one, with a folkloric base that has little relation to the Judeo-Christian tradition. However, as it will be shown later, the treatment given to that folklore very often differs from the way in which Westerners understand art.

Folkloric and popular Japanese material have different sources, yet all end up referring to the two main religions in Japan: Buddhism and Shinto (Miller, 1987; Anesaki, 1996; Kawasaki, 2006; Caeiro, 2009). Shinto is the native religion in the country with a basically animist base. For Shinto, there is an undetermined number of gods existing in heaven and on earth, and all of them deserve to be worshipped. Many entities can be considered a kami (god), and therefore, be treated as a divinity: for example, a natural phenomenon, an outstanding ancestor, an ancient tree.

Shinto religion accepts that the heart of a man is 'full of light' and that the personality, properly trained in proper behaviour during life, survives death and eventually melds into the kami devoted to one's family (Littleton 2002:90-91)

Strange as it may seem, Shinto has neither a holy book nor specially designed rites. It does not even describe a moral system in the way Catholicism does. As stated by Levi (2006:45), for many Japanese it is an accumulation of superstitions and customs that remain uncodified and function successfully as a religion. But it contains an idea that helps its coherence, that is, 'The way of worship is primarily that of preserving and cultivating purity of heart' (Campbell 2004:181). Shinto is of vital importance to the essence of Japan as it includes the mythologies about the origin of the country, the origin of the world, and a rich major symbology related to Shinto legends.

The other main religion, Buddhism, entered Japan from China along with the writing system, and its propagation was very fast. Both religions coexist in a perfect interrelationship (Levi, 2006:33-57; Caeiro 1996:10). Neither of these two religions exclude each other and many Japanese people have both a Shinto and a Buddhist shrine in the same room of the house. It is tradition to say that a Japanese 
person is born into the Shinto religion, marries as a Christian and then dies as a Buddhist, as there is no contradiction for Japanese people in mixing these religions. According to Adam Barkman (2010), Japanese society is generally pluralist regarding religion. He says

Thus, the important thing for the pluralist isn't propositional truths or doctrines about Ultimate Reality; rather, the important thing is perceived personal salvation or transformation. Accordingly, the pluralist typically accuses those who make much of religious doctrines of intolerance (p.27).

Although the use of one's own energy as a weapon or the conception of an eternal 'soul' are not original (just think of Ghost in the Shell (Mamoru Oshii, 1995) or Akira (Katsuhiro Otomo, 1998)) both of them are fundamental in Dragon Ball. The Kame-hame-ha Wave - energy that emerges from the inside of fighters - is the distinctive technique for the disciples of Kame Sennin and Son Goku, the main character, dies and goes to heaven where he get more training before coming back, alive, to the Earth. On the other side, from the beginning of the series Goku is the clearest example of 'purity of heart' that the Shinto doctrine also pursues.

Other forms of religion and moral doctrine have influenced Japanese culture, namely Taoism and the Confucius Doctrine. In the case of Taoism, there is less influence, but given the permeability of Japanese beliefs, some deities and customs of divination techniques have been incorporated into the daily life of Japanese people (Levi, 2006:56). Confucianism has deeply influenced Japanese society by providing a moral backdrop focused on the family as the centre of everything and with a hierarchical structure, which even today remains largely unshaken. Relations between 'Senpai' (upper social status, either a chief or elder brother) and 'Kohai' (lower status) extend even to the Japanese language, which has different ways of speaking depending on the position in the hierarchy of the speaker and the listener. Those relations are presents in Dragon Ball as well as the giri (debt of gratitude) towards the master Kame Sennin or Goku’s ancestors.

It is important to discuss religion in Japan because purely folkloric material is not so abundant.. According to Luis Caeiro (1996:14), it is difficult to distinguish between religious and folkloric material. A basic book for Shinto, such as the Kojiki (Yasumaro, 1981), is described in some sources as religious, in others as historical, and in others as folkloric. In Miller’s (1987) words: ‘ [...] the folktales at a later stage may have borrowed from the myth: that is, the folktales may have been kept alive and growing by the fact of the establishment of the myth (p.326)'. But Miller distinguishes between both concepts.

In the myth [...] its redundancies, and its oscillations, the structure seems to be the more vital, necessary part of the message, with the personae changing as needed. The structure is repeated with different 
characters; the symbols appear in one repetition and not in another. In the folktale, the structure is simple and the personae are far more fixed to it: the structure is used only once in most cases and in only one way [...] The small world of the folktale is a sphere of meaning that is circumscribed by the limited concerns of the ordinary people [...] Myth - at least these myths - uses the same figures and symbolizes them in some of the same ways, but myth makes them function as cosmic beings, creating and modifying the world itself, the great world, the world on which everything else - all the little worlds depends. (p.327)

Apart from the relationship between myth and folklore we must consider the differences between Western and Eastern folktale traditions. According to Yoko Kawasaki (2006:1-2), the Japanese 'type tale' differs considerably from the traditional European tales. Propp (1968) uses this concept to define a structure that remains unchanged in every story appealing to a universal common ground of narrative. I shall not go into the polemic about the universality of Propp's works as he did intend to build a theory of narrative rather than a theory of myth (see Dundes, 1987, Hyvärinen 2012, Uther 2000). It is usually assumed that the Proppian model fails when applied to culturally specific examples, especially in nonEuropean cultures. Japan is not an exception.

Kawasaki (2006) states: 'It [the type tale] cannot be applied exactly in Japan. In Japanese tales, similar stories with the same theme appear in different ways compared to Western tales, regarding its basic structure' (p.1-2). Kawasaki writes specially about the short stories in which an animal is transformed into a person to marry the main character. She demonstrates that both the endings and the justification underlying the short story are profoundly different. In fact, another difference she highlights is precisely the absence of a happy ending in Japanese short stories.

The open ending, which contrasts with the clear sense of a happy ending seen in most European fairy tales, is a classical closure for Japanese tales. Since no concept of magic can be seen in the process of transformation, it is done through an unclear process and the readers are not fully told how the animal transforms into a human. The subtlety in this moment of transformation in Japanese tales implicitly indicates that an animal having a human appearance is a natural phenomenon. (p. 19)

We can find this open ending or even sad endings in folktales like 'Urashima Tarō'(name of a fisherman) or 'The crane wife’ (Tsuru no Ongaeshi). Another difference, which is linked very clearly to the Judeo-Christian roots of Western culture, is found in the lack of punishment for the breaking of a taboo or prohibition. For Propp, it is one of his 31 main functions, while for Japan, disobedience is not necessarily punished. As stated by Kawasaki (2006:42-43) in reference to the story of 'Crane Wife', the imposition of the taboo is shown in the West (following Bettelheim, 1999) as a sign of trust. In 
Japan, what they condemn in the story is the marriage between humans and animals, since the interest is focused on human-nature interaction. As another demonstration of the difference between both traditions, she adds:

The world presented in the Western tales is at a much realistic level. Hence, these tales offer a representation of the realistic social realm. Aspects of supernatural are deployed in order to learn mastery over them and animals are merely metaphors of humans. On the other hand, in Japanese tales aspects of supernatural are stronger and are not portrayed to learn total control but to show the culture's interpretation of the world. (Kawasaki, 2006:43)

Thus, some characteristics in Dragon Ball would be expected to be associated with folk formulas that do not meet Western expectations. The surprising endings of some chapters, the weird scale of values, even the relationship between characters, responds to a tradition strange in Western countries but that it is present in Japanese folktales.

Yet it is important to understand that Japan has been a recipient of cultural products from various origins (Levi, 2006:63). European folk tales (especially the Grimm and Perrault versions) were widely accepted by Japanese society. Today, such folk tales are present in Japanese culture; but just like in the West, they are deeply influenced by the Disney Corporation's interpretation of them (Lluch, 2000; Ellis, 2010:249-254). Nowadays, people does not remember tales such as 'Cinderella', 'Snow White' or 'Sleeping Beauty' from the Grimm's or Perrault's versions, but usually associate them with the Disney classic animation features. Therefore, it is not uncommon to find references to European stories in anime since some of them enjoyed some popularity among Japanese viewers. In many cases, they have been 'Japanised' or adapted to Japanese culture depending on the influence they have had. One example of this appropriation is the book Érase 21 Caperucitas Rojas (Once Upon... 21 Times, Little Red Riding Hood, Ayabo et alii. 2006) where 21 Japanese authors illustrated the popular tale according to different and original rules.

Despite Propp's model not accounting for the specifics of cultural difference, it is possible to find a certain interrelationship between Propp’s 31 functions and Japanese tales, since they include many narrative actions and formulaic conventions that are very common in most parts of the world though they are not completely universal. Talismans, heroes, journeys, etc. are as much part of the common ground of folktales as they are for animes like Dragon Ball. Such features appeal to our knowledge of the folktale world in order to make stories more understandable. It is easier to follow a TV series if we expect it will have the structure of a traditional story or if the hero will accomplish the rule s/he is usually assigned to do. However, these features are characteristics of folktales, not of anime. Every anime feature-length film has an author who is responsible for the plot, the characters, etc. As a popular product, we can find traces of folktales in many Japanese TV shows, but they will not be considered 
strictly folktales (they have a recognised author, they do not come from a popular and ancient source, etc.) and, consequently, the methodology cannot be the same. In fact, part of the resources Dragon Ball uses, are about the subversion of the rules of folktales.

Finally, although from a Western point of view, the Samurai stories compiled in various forms (novels, theatre, tales, etc.) would not be considered strictly folklore, they form a fairly homogenous set of short stories. Luis Caeiro, in fact, devotes an entire volume of his collection to those stories (Caeiro 2005). They often mix divinity with humanity, and they try to exalt some values that Tsunetomo Yamamoto tried to capture in his book Hagakure (1700/1979). The Samurai stories are, in many cases, a nostalgic look at values that lost their meaning in the Tokugawa Era (1601-1868), during which the wars that had ravaged the country for many centuries ceased. As a matter of fact, Hagakure was written at that exact time, just like The Five Rings by Miyamoto Musashi (1645/1993). Both books represented a memory of what the Samurai were in their time, rather than a reflection of what they experienced. and both are linked with the common thinking of Japanese people. In Dragon Ball, as a martial arts anime, is easy to find in all the main characters but especially in Son Goku the eight virtues of samurais that Nitobe Inazo (1900) found in Bushido: rectitude, courage, benevolence, politeness, sincerity, honour, loyalty and self-control.

The use of folklore and myth to create parodies is a very common resource in postmodern culture. What Rodari (1996) called ‘fairy tale-salad’ is a usual genre in actual Children's Literature. It is easy to find many examples for children and adult like Hoodwinked! (Edwards 2005), Once upon a time (Kitsis and Horowitz 2011) or, especially, the Shrek saga (Adamson et alii 2001-2010). Mínguez (2012) shows how the authors of these films employ the traditional fairy tales with many other cultural references like the USA popular culture, the action cinema or the videogames to create a subversive material: intertextuality as a subversive weapon. It feeds the knowledge of folktales, it disseminates these stories and, at the same time, it questions them. This is also the case of Dragon Ball.

\section{Dragon Ball or The Journey to the West}

Dragon Ball (in English in the original version) was published between 1984 and 1995 in weekly instalments in the magazine Shonen Jump. Later on, it was published as an independent comic book, while at the same time it began its television broadcasting in 153 episodes. The success of the series led to its continuation. Dragon Ball continued its publication in the magazine Shonen Jump and in its TV adaptation. However, for the anime version, the name was changed to Dragon ball Z from Episode 197 of the manga series; maybe because the plot differed from the original. Subsequently, the producer 
decided to continue the series with Dragon Ball GT, in which Toriyama would only act as a consultant. Finally, a final remastering of the TV series would still be published under the name Dragon ball Kai and Dragon ball Z Kai. There were also a total of 17 OVAs (Original Video Animation) produced based on the TV show (Bermúdez, 1995; Okuhara, 2010:202).

In the 1990s, anime appeared on European television (Spain, France, Germany, Italy...) causing a mixture of admiration and amazement due to the display of unusual resources hardly ever seen in usual cartoons. The action scenes, humour and occasional touches of eroticism were a combination that had no prominent place on television up to that time (Bermúdez, 1995). With it also caused controversy due to the violence of some scenes and the alleged sexism of others. This led to its withdrawal from several public television stations (in Spain for instance from many regional TVs) but it was not eliminated from the screen altogether because other private TV companies (Antena 3 in Spain) broadcast them anyway. The scenes suffered considerable censorship all around the world as declared by the distributors themselves who sell copies 'Uncensored' (Montosi 2009, Okuhara 2010).

In this article, I will only refer to what was known in Europe as Dragon Ball - in other words, the first 197 episodes of the comic book, and the 153 episodes of the TV show. The reason is, firstly, to shorten a study that otherwise would be too broad (there are 291 episodes of Dragon ball Z and 64 episodes of Dragon ball GT). Additionally, I believe that the perpetuation of the story also led to its simplification and reduction to become a never-ending battle which fails to incorporate the folkloric and literary richness that is found in the first series.

I would like to show how Dragon Ball is constructed on folkloric basis. These basis, however, are used in different ways by the author in order to create different effects. The main one is probably the subversion, but it is intertwined with a serious or more conventional use and with simple puns. All of these uses do not exclude the others and the result is a very original product that continually surprises the audience. I personally think that, though parody and grotesque is not unusual in anime, the final result of Dragon Ball is difficult to find in other films and series, and this is what makes it more valuable.

The first important link we can find between traditional short stories and Dragon Ball is precisely its origin. 'Sun Wukon' ('Son Goku' in Japanese), the Monkey King, is one of the characters in Journey to the West (Cheng'en Wu 1993). This book has been widely distributed in the East. It is a classic 16th century Chinese book in which Xuanzang, a Buddhist monk (a real historical character) starts a journey to India in search of Buddhist sutras. He is accompanied by three characters, including Son Goku, a playful Monkey King, who stands out in particular. He is known for his great strength and for having 
the ability of creating a cloud with which he is able to fly. He also carries a staff, which has the ability of being extended at will (see figure 2). Besides these two characters, there are other travelling companions: a pig-god punished on Earth for lustful behaviour and another disgraced character who was turned into a water demon (in Japan it is often characterized as a kappa, a local monster that resembles a human-like frog with a patch on his head which is full of water). We must consider that, besides the classic novel, there was a TV series that made the Journey to the West popular on Japanese television in the 1980s.

Figure 1

Sun Wukong the monkey king in a 19th century version of Journey to the West.

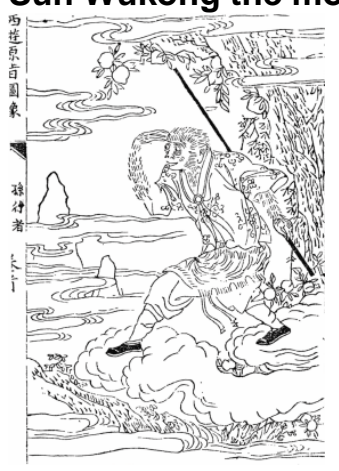

In Toriyama’s creation, we find a monkey-tailed boy living alone in the mountains, a kind of feral child who embodies absolute innocence even when he is endowed with great strength (Figure 2). Bulma meets him in the story; she is a young genius who is searching for a type of orange ball, and there are seven of these balls which she must find. According to what she tells Son Goku, the person who gathers the seven dragon balls may summon the dragon Shen-Long who will grant them any wish. The boy decides to join Bulma to get the balls in an attempt to resurrect his grandfather, who died years before. We learn from the story that the grandfather gave him intensive martial-arts training before dying. On their way, they find the first Dragon Ball in Oolong's hands, a shapeshifting, antropomorphic pig. He joins Goku and Bulma in the search for the dragon balls to eventually steal them, but abandons this plan. They also meet an old man called Kame Sennin (also called MutenRoshi), who gives them another ball and a cloud called Kinton, with which Goku can fly. Kame Sennin demonstrates his huge power with his Kame-hame-ha Wave and Goku, impressed, decides to follow him as a disciple after gathering the seven Dragon Balls. Another main character they find on the journey is Yamcha, a bandit who has no confidence when talking to girls and who follows them to steal the balls in order to ask for this confidence. He is accompanied by Puar, another shapeshifting character who went to the same shapeshifting school as Oolong. These characters, besides other secondary 
characters, form the crew of the very first part of the anime that finishes with the appearance of the Dragon called by Pilaf, a man who dreams of ruling the world and who previously stole the balls. However, Oolong manages to ask the dragon for a wish, before Pilaf can ask for his wish. Surprisingly, the wish consists of a pair of girl's panties.

\section{Figure 2}

Son Goku showing the staff and the monkey tail, Dragon Ball (1986)

(C)Toei Animation

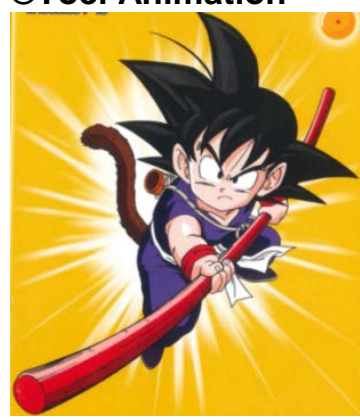

After these 20 episodes the structure of the anime changes and it alternates the plot of searching for the dragon balls with the plot of the Martial Arts Championships. Son Goku decides to train with the Kame Sennin and a new character called Krilin will join him. Piccolo Daimao (or Satan) appears in the last part (or saga) of this long succession of Tournaments. He is another character who aspires to dominate the earth. In order to defeat him, Son Goku will be assisted by Kamisama (God) and he will be able to beat Piccolo Daimao and later his son, Piccolo.

The parallelism and parody of Journey to the West starts with the main character, Son Goku. He is not a monkey, but a child; but he has a monkey's tail (a bond to his origins). To complete his ties to the classic character, the boy becomes a terrible monster (Ōzaru, a giant monkey) when he sees the full moon. He also carries a couple of talismans but Toriyama decides to give them a different origin. On the one hand, the cane that stretches (nyouibou) turns out to be a gift from his grandfather. On the other hand, Kinton cloud, with which he can fly, it will be a gift from the mysterious Kame Sennin or Elf, Genie or Wise Turtle and it has the unique characteristic that only someone with a pure heart can get onto it. The test that the hero endures in order to obtain it (as in Propp's (1968) functions) is easily passed by Goku, who rides for most of the series on the Kinton cloud. He just demonstrates his purity of heart, a Shinto value as mentioned above. Toriyama even makes a final bond to the original novel when in Episode 130 Mr. Popo takes one of his hairs to create a double of Son Goku - a capability that is also possessed by the Monkey King in Journey to the West.

References to the Journey to the West continue because, despite not seeing a kappa in Toriyama's version, a little pig does appear who is given the name of a popular Chinese tea, Oolong, and he actually wears a Mao suit. In addition, Oolong is able to transform himself, as the original Zhu Bajié 
from the novel, who dominates 18 forms of transformation (Son Goku dominated 72, even when Toriyama did not include this feature in his character), and paralleling Journey to the West, he also behaves in a rather lustful way. Zhu Bajié kidnaps a young girl to satisfy his sexual desire as does Oolong by kidnapping girls and terrorizing their village with his transformations. However, as a part of the parody and unlike the novel, the young women who have been kidnapped have an easy life at his expense.

\section{Other Chinese references}

Up to this point, Dragon Ball could be considered just a parody of Journey to the West but it is enriched with many other references and word games. Oolong is not the only name which is used as word play: Yamcha is also the name of a popular Chinese tea, and Pilaf, a villain who tries to steal the Dragon Balls, is also the name of a type of cooking rice in the west of Asia. References to Journey to the West intersect with the Japanese love for Chinese martial arts movies in general and in particular those of Jackie Chan (Levi, 2006: 82-83). Therefore, besides dressing up numerous characters in Chinese clothes, some characters have Chinese names or Chinese-sounding names such as Tao Pai Pai, Ten Shin Han (who has a third eye, a feature that connects him with a Buddhist and Hindu belief) or Jackie Chun (an alter ego for the Kame Sennin) (figure 3). Another important character is Krilin (figure 4), who has no Chinese name despite wearing the clothes of a Shaolin monk and having six points on his head, which are characteristic of these monks. He is called Kuririn in Japanese, suspiciously like the famous Japanese beer Kirin.

\section{Figure 3}

Jackie Chun with Chinese clothes, Dragon Ball (1986)

CToei Animation

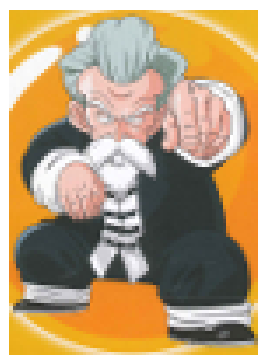

Figure 4

Krilin with Shaolin clothes, Dragon Ball (1986)

CToei Animation 


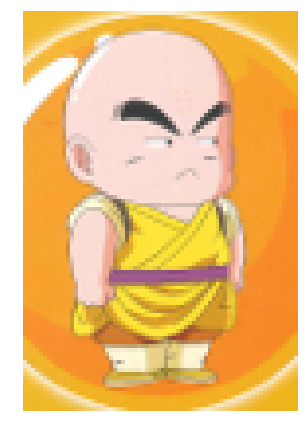

It is evident that Toriyama likes to play with words: besides the names of Chinese tea (Yamcha, Oolong, and Puar) we can also find Chichi (as in Chichester milk, even when 'chichi' can also mean 'breasts' in Japanese), Bulma (pronounced Buruma in Japanese, like bloomers, i.e. 'shorts'), the terrible Freezer (pronounced furiza in Japanese), Gohan (Son Goku’s grandfather), and Son Gohan (his son). The last two characters take their names from steamed rice which is served with almost all Japanese dishes. With these innocent games I suggest that Toriyama aims to make reference to everyday things that Japanese people think of as typically Chinese, and that he also uses them because of the different sonority that Chinese names have compared with Japanese ones. He plays with language and he constantly tries to break the normal flow of the story. Despite these nods to the reader and viewer, the key references are still Japanese. These puns and allusions to Chinese culture are a rather comical use of common places things.

There are more references; in some cases, Toriyama uses Chinese mythology consciously as a source of inspiration, recovering in some way the original purpose of the myth. The dragon Shen-long is one of the seven Chinese celestial dragons, precisely those who carry clouds and rain. From here, he just takes the name, the concept of a divine dragon and an oriental dragon shape, but it neither links Shenlong with its Chinese origins nor gives any further meaning to the use of his name. In Chinese mythology, Shen-long neither grants wishes nor has anything to do with the seven magic balls; however it is a fundamental reference in Chinese imagery. In spite of the distance from the traditional dragon, Shen-Long always appears in the series with an aura of respect, as if it was something too important to joke about. This coincides with central points of the plot, and the characters can break the seriousness of the scene (Oolong wish, for instance) but the dragon always remains solemn (see figure 5).

\section{Figure 5}

\section{Shen-long appearing to grant a wish, Dragon Ball (1986)}




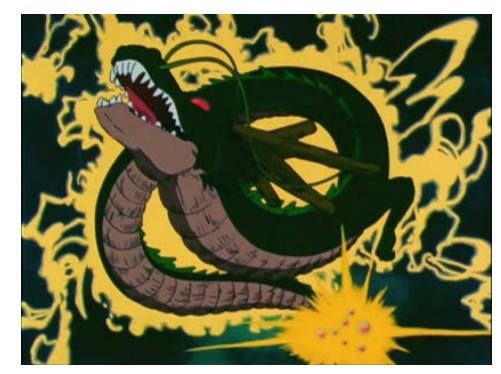

Let us pause for a moment to analyse the character of Kame Sennin (Genius Turtle) as it offers a wealth of jokes and puns that show the usage of references in anime. The Sennin are usually hermits who are devoted to meditation. It is possible Toriyama based this character on the monk Xuanzeng, or perhaps he mixed this with the figure of the kappa, which is also represented with a shell on its back. In any case, the concept of Kame (turtle in Japanese) is evident and a character is created who lives in a house called Kame house and always carries a huge turtle shell on his back for strength training. His best known technique is the Kame-hame-ha, which, apart from containing the word kame, turns out to be the name of the last dynasty of Hawaian kings before the American occupation. And where does the Kame Sennin live? He lives on an island in the Pacific, accompanied by a turtle and is usually dressed in shirts that resemble the typical Hawaiian shirts (figure 6). To complete the parody, rather than a reclusive hermit in search of perfection, he is a lustful old man that lives a chaotic daily life, and who is obsessed with pretty girls.

\section{Figure 6}

Kame Sennin on a turtle and near the Kame House, Dragon Ball (1986)

(CToei Animation

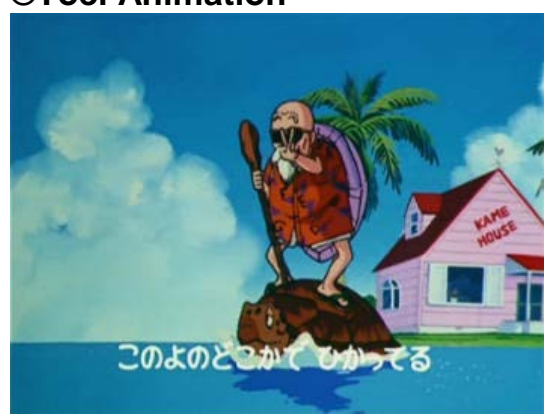

\section{Influence of Japanese Folktales}

As we have seen so far, the references (both from oral and written tradition) are rewritten in a very peculiar way in Dragon Ball not only because of the clear disregard for the original sources, but also because of their reworked connections. In Japanese animation, it is not very common to see such an accurate recreation of a classic work, since what is most valued (in this kind of animation) is the use of imagination to create fantastic new worlds, even if they are not coherent. In the case of Dragon Ball, for example, we can see how Goku lives in the mountains accompanied by antediluvian monsters 
which he must sometimes face. But Bulma appears riding various vehicles stored in capsules that contain all sorts of useful tools for her journey. Beyond the mountains where Goku lives there are desert landscapes that alternate with the Pacific Ocean, semi-primitive towns comprising futuristic houses, gas stations and even televisions. In anime anything is feasible, because the main objective of the authors is not to build up consistent or predictable worlds, but just the opposite (Levi, 2006).

Regarding traditional tales, we can say that they are present in Dragon Ball from the beginning. They represent a background which helps in building the entire story by providing easily recognisable characters, morality and magic elements. Folktales also provide a background for supernatural events such as resurrection. The character Son Goku, apart from containing the elements discussed earlier, is the stereotype of a small character that manages to win thanks to his special gifts. This character appears in many cultures and can be seen in Perrault's Le petit Poucet, Grimm's Daumestick, the Castilian Garbancito, the Catalan Patufet or Nabet, the English Tom Thumb, and of course in the Japanese Issunboushi (literally 'child of an inch'). Also, the development of the first part of the series in which the characters search for the dragon balls is a legacy from folkloric tradition. The idea of a voyage of initiation in which different tests must be overcome and in which (as in Western ways), the triumph of good over evil is related to Propp’s (1968) famous 31 functions, even if they are not completely fulfilled.

Traditional short stories probably serve to make it easier for the audience to find references. Many of the characters that appears in Dragon Ball are familiar to Japanese in other forms (usually, traditional tales) and its characteristics can be related with its origins. For example, as mentioned before, Oolong is able to transform himself into anything within 5 minutes. This capability is used to frighten the inhabitants of a small town with monstrous forms (Episode 4). One of the monsters he utilises is an Oni, an ogre characterised in the Japanese tradition (see figure 7): red, with horns, big mouth, and so on (the kind of monster that is often depicted in Japanese temples, see figure 8). Another traditional character that appears in the series (Episode 9) is a rabbit that terrorizes another village with his group of gangsters, also called Rabbits. Even if there is no short story in which a rabbit threatens a city as a mobster, Toriyama relates the end of the episode to a different Japanese legend. In Toriyama's ending, Son Goku takes the Rabbit and his allies to the moon, like in the Japanese legend in which there is a rabbit living on the moon that makes mochi (a type of rice cake) by smashing rice.

\section{Figure 7}

\section{Oolong characterised as an Oni, Dragon Ball (1986)}

CToei Animation 


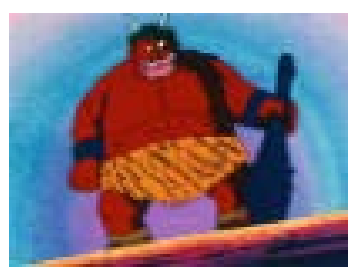

\section{Figure 8}

\section{An Oni in a Japanese temple, own resources (2006)}

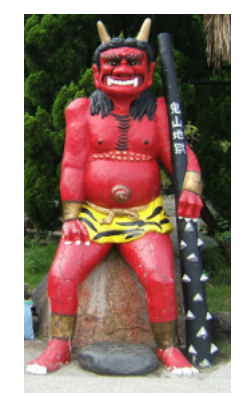

But the most obvious reminiscence of the Japanese folktales in Dragon Ball is certainly the treatment of the characters, the plot and the moral message implied.The evolution of the characters shows a departure from the usual Manichaeism in Western folktales. Many evil characters switch sides for different reasons. Sometimes, this is because they understand that goodness has a greater consistent value than evil (like Ten Shin Han), and on other occasions, it is for self-protection or because they have become attached to the main characters (Yamcha's case). In other cases, it is due to diverse unknown reasons (some even quite difficult to explain), just like the case of Oolong, who decides to join Bulma and Yamcha so as not to be alone, or the case of Yajirobe, who accompanies Goku because he promises him enormous amounts of food.

Many of the seemingly magical elements that appear in the story are not presented as magic, but instead are the result of the superpowers of the characters. Very often, simply, they are not explained, since they are part of their own characteristics. The magic elements or those that empower the character, in many cases, lose their value as talismans - in Propp's classification, they have a crucial role in the climax of the story - and become a complement to the fantasy of the series. This is the case of Senzu beans, which rejuvenate and restructure the energy of those who take them. At first, it is almost a secret of Son Goku, but as the story moves on, it turns out that the whole team has them. Something similar happens with the Kame-hame-ha. The energy wave that is a display of strength at the beginning, later becomes a unique mark of all the Kame Fighting Group’ members.

Within this magical or supernatural phase, we can also find the treatment of death, which is not shown as an end, but rather as a state. This approach clearly has its roots in Japanese religions, especially Buddhism and its belief in reincarnation. Several characters die at some point in the story (even Son 
Goku dies in the continuation of the series), but they are brought back to life through the intervention of the dragon Shen-long. Likewise, the mortification of the bodies of the fighters is seen as necessary in a bloody fight but they are wiped out with the ingestion of the Senzu beans. The cruel Tao Pai Pai is also revived when he is transformed into a robot-human hybrid. The body in anime is a kind of shell or a mannequin (Brophy 2005) that contains the most important things in the living being such as Ki (energy). In this way, not even death can erase the person as a whole. Even death, which seemed final to Piccolo Daimao (Satan in some translations) is followed by the sudden birth of his son, a reincarnation of his father who even inherits his memories and plans his revenge (Episode 122).

Related to both Japanese religion and folklore, we can find an important resource: transformations of all kinds. The most obvious ones are those experienced by Oolong's and Puar's, who are capable of becoming anything, while maintaining their original strength. But we can also find transformations such as that of Son Goku, who turns into an Ōzaru, the giant ape, a werewolf into a man (Episode 89) or the ability of Piccolo (son) to become a giant (Episode 145). As in folk tales, no explanation is given as to why these beings are able to transform themselves. It simply happens.

The ending is left open, as in many traditional Japanese stories, and it is not necessarily happy because, for example, if Piccolo is left alive, there is the possibility that he will continue to spread his evil. Similarly, there is no need for the author to show realism in his construction of the world, but rather it is used to display values like loyalty, friendship, sacrifice, and so on, linked to the values attributed to the Samurai. Indeed, as I mentioned before, Samurai stories, even though they are not strictly folklore (as they do not always have an oral origin), are ubiquitous in anime, especially in action anime. In Dragon Ball we see the reflection of the virtues extolled by both Yamamoto (1700/1979) and Miyamoto (1645/1993) in their books about Budō, and gathered by Inazo (1900). They are embodied at the beginning in Son Goku but are gradually extended towards his companions when Dragon Ball becomes a martial arts series.

In this part of the series, the influence of Zen Buddhism is of prime importance, or better said, the view that both the stories of Samurai and Budokas (practitioners of oriental martial arts) have transmitted. In Dragon Ball, Son Goku and his colleagues improve their skills thanks to hard training. But Son Goku begins a journey on a different level to that of his peers when he goes to the tower of Karin and starts practicing with Kamisama. He tries to make him see that he has to empty his mind in order to become a good fighter, as taught in Zen meditation. Not fighting an unequal struggle, respecting the enemy, striving against oneself (not against others) in order to improve as a fighter, etc. are basic lessons in Zen. Many scenes summarize very well the classical values of Samurais as seen in works dealing with 
Zen in the martial arts (Deshimaru, 2000). Son Goku's honesty will even lead him to marry Chichi several years later (engaged to each other since childhood). Despite not being convinced of the idea, Goku decides to be faithful to his promise and to raise a family. That helps to reinforce the importance of family, which is part of the Confucius doctrine and continues in Japan, despite the apparent disintegration of the family unit.

To conclude this section I would like to reflect on two characters who may be quite puzzling to the Western viewer, despite having an obvious bond with Eastern culture and the concept of opposites (yin and yang). I am talking about the characters Kamisama and Piccolo Daimao, translated with relative success in some versions as God and Satan (figure 9). Although the name Piccolo comes from a musical instrument (recalling Toriyama's habit of making puns on the names), Daimao would come to mean Great King Satan. Kamisama, however, doubtlessly means God. To reinforce this meaning, they have both written their names on their chests with a Japanese ideogram meaning 'God' and 'Satan', Obviously, we have to go back to the Eastern origins of anime and understand that a kami is not necessarily God and a demon is not necessarily the Devil. If we recall the basis of both Shinto and Buddhism, we see that there is a multitude of gods on Japanese Olympus and that the category of god can be attributed to a number of ancestors, natural accidents, phenomena, etc. Furthermore, Barkman (2010) explains this dualism compared with Christianity:

Of course the idea that there is a balance between good and evil is I Ching philosophy (which predates both Taoism and Confucianism) and not Christianity since the I Ching seems to endorse metaphysical dualism or the belief that good and evil are both positive, coeternal substances, whereas Christianity maintains that God, who is Goodness itself, only made good things, and so evil must simply be the absence or privation of a good that should be present (p. 35).

\section{Figure 9}

\section{Piccolo Daimao and Kamisama. They wear different ideograms to distinghish each other, Dragon Ball (1986)}

(T)Toei Animation

The ideograms that appear in the chest of the characters give some information about them. Usually the name of the character is written, but any personal characteristic can also appear (Yamcha has written 'joy' in his chest), as well as some feature of the team (the followers of the Genius Turtle show = 'Turtle', the rabbits 'Rabbit'), etc. 


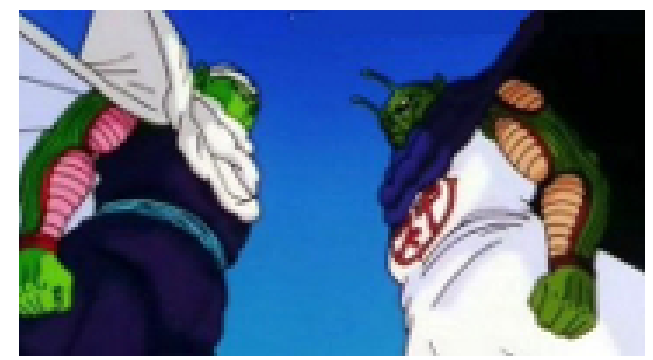

\section{Folktales and myths in other anime}

Thus, in the examples I have shown we can see that folktales and religion are a constitutive part of Dragon Ball. However, these references to tradition are not always depicted respectfully; they change from the solemnity of a God announcing the resurrection of Shen-long to the image of a child jumping of joy and from the imposing appearing of the dragon to a girl's underwear flying through the screen. This structure of tradition and religion, is constantly undermined to create humorous scenes but, above all, to create the impression that it is something we can laugh with.

Dragon Ball uses folkloric, religious and cultural material in a different way to other kinds of anime. Many series and films like Neon Genesis Evangelion (Hideaki Anno, 1995) rely on the audience's knowledge of one character or one single story and then build a story from there. Barkman (2010) draws attention to the treatment of Christianity in anime and manga and he emphasizes that 'I do admit that when the Japanese deal with Christianity in their anime and manga, it's more for literary effect than for philosophical debate: symbols, more than syllogisms, are what most Japanese anime and manga artists are concerned with' (p.36). In Neon Genesis Evangelion (Hideaki Anno, 1995), Eva is a robot who is able to defend mankind from the threat of aliens (called Angels) which already destroyed the Earth. The new Genesis - that draws parallels to the Christian and Jewish book of Revelation - is, consequently, the new chance that this robot gives to human beings to live on. Very few, and quite odd, references to the Christian Bible are made. Barkman gives another example of the use of Christian stories with Spriggan (Hiroshi Takashige, 1989); in this anime 'Noah is an alien spaceship that landed on the Earth and, due to its power to control weather, was the cause of the flood and the subsequent ice age' (p.33). Again, the hypotext is reinterpreted to give a background to the story without any relation to the original source. Many other animes follow the classical or folklorical reference in a parallel way. This is the case in Heidi, Girl of the Alps (Isao Takahata, 1974) or Ulisses 31 (Nagahama Tadao, 1981), which uses the plot of the original novel (Spiri's book respectively and Homer's Odyssey) and makes it recognisable.

The works of Hayao Miyazaki, which include many folkloric references, are also slightly different from Dragon Ball. Miyazaki usually includes this material in order to vindicate Japanese traditions and 
their cultural background (Price, 2001; Reider, 2005). In Miyazaki’s Spirited Away (2001), for instance, the main scene is a crowded hot spring for gods of all kinds. The antagonist, Yubaba, strikes us as a descendent of a yamauba, a traditional Japanese witch who takes care of her very big son, who is also like Kintarō, the gigantic son of yamauba; Kamaji is a tsuchigumo or earth spider; Haku is a river deity, etc. (Reider, 2005). Although Miyazaki modifies some characters to adapt them to the plot, he remains very faithful to tradition. He neither parodies, nor ridicules.

Of course, the idea for Dragon Ball does not merely come out of the blue. The tradition of melting pot and absurdity is present in other animes such as Rumiko Takahashi’s Ranma 1/2 (1987) or Toru Fujisawa’s Great Teacher Onitzuka (1997). Nevertheless, the originality of Dragon Ball does not lie in the sources he utilises, but in the combination of them. On the one hand we find parallels with Journey to the West and the teasing tone that is always present with the parody of the characters. On the other hand there are the influences of folkloric materials, including samurai stories, that appeal to the Japanese and, likely, awaken much more reminiscences in Eastern audiences than in Western ones. And finally there is the wide range of puns and jokes about each character that very often are intertwined with other references which can lead to a sense of the absurd. It shapes a cultural fusion of special singularity.

\section{Conclusion}

As we have seen, the ties between Japanese animation and folk tradition are more than evident. In spite of the westernised appearance that is often attributed to Japanese modern culture, the fact is that the Japanese people keep their customs intact, including their permeability to other cultural forms, which usually are Japanised for better understanding and ownership. Religion is possibly the cultural aspect from which one can get the most regarding cultural performance in a comparative analysis. The system of values, myths and morals of the major religions in Japan offers a framework which is radically different from the Judeo-Christian one which we are used to, which often creates confusion or misreading of the visual product. But also, Eastern folkloric material stems from different models from those of the West. It offers a wealth of references that unfortunately we can only partially understand since knowledge of oral traditional Japanese literature is still quite basic in Europe.

Dragon Ball has actually been a victim of erroneous readings. It rereads not only Western but especially Eastern sources to meld them into a multi-layered, multicultural and very open product. Withdrawal and censorship are part of this misunderstanding, which should be overcome in order to make a more constructive relationship between the East and the West. In my opinion, this work shows 
a remarkable literary wealth through the constant cross referencing of literary, cultural and folkloric references that shows the creativity of its author, Akira Toriyama, and his ability to use intertextuality to create and recreate fantasy worlds; this is an ability that I consider unique. Even if there are other anime using a novel as a background and anime that use folktales references, the particular combination of these resources with a sense of humour close to absurdity, is probably one of the outstanding features of Toriyama's works.

However, we have also seen how Dragon Ball appeals to more common motifs, like the fight between Good and Evil, honour, the appearance of talismans, the journey, and the role of the hero. It could be said that these motifs are universal and, therefore, they are linked with the thought process of human beings. But it is obvious that their interpretation is culturally influenced. The struggle between Good and Evil is not resolved because of the impossibility to divide one from the other.

Nonetheless the most difficult reading from a Western point of view is the subversion that lies in the particular use of folktales and myths. If both, folktales and myths, are the World's View of any nation, then to question them also means to question its society pillars. Even when Toriyama does not pretend to undermine the authority of the tradition, it is almost impossible to manipulate folktales and myth without appealing to the Japanese World's View. Consciously or not, there is a subversive message for the audience and it keeps distance from the reverential treatment of other authors like Miyazaki, for instance. In sum, intertextuality remains a weapon for subversion. 


\section{References}

Barkman A (2010) Anime, Manga and Christianity: A Comprehensive Analysis, Journal for the Study of Religions and Ideologies, vol. 9, $\mathrm{n}^{\circ} 27$.

Bermúdez T (1995) Mangavisión.Guía del cómic japonés, Barcelona: Glenat. (Mangavision. Japanese Comic Guide).

Berdnt J (2001) El fenómeno manga, Madrid: Martínez Roca. In German (1995) Das Manga Phenomenon, Berlin: Edition Q.

Bettelheim B (1977) The uses of enchantment: the meaning and importance of fairy tales. New York: Random House.

Brophy Ph (2005) 100 Anime, London: British film Institute.

Caeiro L (1999) Cuentos y leyendas japoneses, Madrid: Hiperión. (Japanese tales and legends)

Cheng'en W (1993) Journey to the West, Beijing: Foreign Languages Press.

Deshimaru T (1982) The Zen Way to Martial Arts: A Japanese Master Reveals the Secrets of the Samurai, New York: Arkana.

Drazen P (2003) Anime explosion! The What? Why? Wow! Of Japanese Animation. Berkeley: Stone Bridge Press.

Dundes A (1997) Binary Opposition in Myth: The Propp/Lévi-Strauss Debate in Retrospect, Western Folklore, 56-1.

Ellis B (2009) 'Folklore and gender inversion in Cardcaptor Sakura', West M (ed) The Japanification of Children’s Popular Culture: From Godzilla to Miyazaki. Lanham, MD: Scarecrow P.

Hyvärinen M (2012) Prototypes, Genres, and Concepts: Travelling with Narratives’ Narrative Works, $2(1)$.

Kawasaki Y (2006) Metamorphosis or Metaphor? Cultural Representations of Animals and Human Transformations in Western Fairytales and Japanese Folktales. MA dissertation. Roehampton:

Roehampton University.

Levi Antonia (1996) Samurai from outer space. Understanding Japanese Animation. Illinois: Open Court.

Littleton, C. Scott (2002) Shinto: Origins, Rituals, Festivals, Spirits, Sacred Places. New York: Oxford University Press.

Hatayama H (2009) 'The cross-cultural appeal of the characters in Manga and Animé', West M (ed) The Japanification of Children's Popular Culture: From Godzilla to Miyazaki. Lanham, MD: Scarecrow. 
Lluch G (2000) De la literatura oral a la narrativa per a infants, Alzira: Bromera. (From oral literatura to children's narrative).

Miyamoto M (1993) The five rings, Boston: Shambala pubblications

Napier SJ (2005) Animé: from Akira to Howl's moving castle: experiencing contemporary Japanese animation. Austin: Palgrave Mc. Millan

Miller A (1987) Of Weavers and Birds: Structure and Symbol in Japanese Myth and Folktale, History of Religions, Col. 26, №3.

Mínguez-López X (1999) El tractament del cos en els OVA's japonesos, Benet V And Nos E, Cuerpos en serie, UJI: Castelló. (The Treatment of Body in Japanese OVA)

Mínguez-López X (2012) Subversión e intertextualidad en la saga Shrek, Didáctica. Lengua y literatura, $\mathrm{N}^{\circ} 24$. (Subversion and Intertextuality in Shrek Saga)

Moist KM and Bartholow M (2007) When Pigs Fly: Anime, Auteurism, and Miyazaki’s Porco Rosso, Animation: an Interdisciplinary Journal, 2(1).

Montosi A (2009) Dragon Ball: evoluzione di un anime Available at http://www.fantascienza.com/magazine/rubriche/12272/2/ (accessed 12 November 2013)

Okuhara R (2009) The Censorship of Japanese Animé in America: Do American Children Need to Be Protected from Dragon Ball?, West M (ed) The Japanification of Children's Popular Culture: From Godzilla to Miyazaki. Lanham, MD: Scarecrow P.

Okuhara R (2000) 'Deja lu or deja entendu’? Comparing a Japanese Fairy Tale with European tales, The Lion and The Unicorn 24, 188-200.

Price Sh (2001) Cartoons from Another Planet: Japanese Animation as Cross-Cultural Communication, Journal of American and Comparative Cultures, 24, 1/2.

Rodari G (1996) Gramar of Fantasy: An Introduction to the Art of Inventing Stories. New York: Teachers \& Writers Collaborative

Reider N (2005) Spirited Away: Film of the Fantastic and Evolving Japanese Folk Symbols, Film Criticism. N. 29, 3.

Uther H (2000) The Third Revision of the Aarne-Thompson Tale Type Index (FFC 184), FFN, $n^{\circ} 20$ Propp V (1968) Morphology of the Folktale, Austin: University of Texas Press.

Yasumaro O (1981) The Kojiki: Records of Ancient Matters. Traslated by Basil Hall Chamberlain. Boston: Tuttle. 